\title{
ANKYLOSING SPONDYLITIS AND PREGNANCY
}

\author{
BY \\ CHARLES LEROY STEINBERG \\ From the Rochester General Hospital, Rochester, New York
}

Much has been written on ankylosing spondylitis but nothing regarding its hindrance to pregnancy or its interference with normal labour. Since this disease is one involving pelvic joints, and since, as the disease progresses, ankylosis of the joints occurs, it is possible that ankylosing spondylitis would be a hindrance in pregnancy and in normal labour. Polley and Slocumb's (1947) short but comprehensive study of 1,035 cases of ankylosing spondylitis is the best appearing in the literature. This series included 931 men and 104 women. The authors made no mention of its association with pregnancy. Undoubtedly some of these women enjoyed the pleasures of connubial relationship which in some must have resulted in gestation. Hench and others (1947) recently reviewed the clinical status of this disease but failed to discuss its effect on pregnancy and labour. Freyberg, in an open discussion of this subject at the March 1947 postgraduate course in rheumatic diseases at the Mayo Clinic, said that he had never known a woman with rheumatoid spondylitis to become pregnant.

The sacro-iliac joints show evidence of arthritis in approximately 99 per cent. of cases of ankylosing spondylitis. The small apophyseal joints of the vertebrae are usually involved later than the sacroiliac joints. On rare occasions $x$-ray evidence is lacking in the sacro-iliac joints but is found in the spine (Buckley, 1936).

\section{Symptoms and Physical Findings}

Low back pain is usually the symptom that brings the patient to the physician. Sciatica was associated, at some period, with the low backache in 25 per cent. of $\mathbf{2 0 0}$ cases observed by the writer. Loss of the lumbar curve with associated rigidity of the spine is usually a late manifestation. Calcification of the longitudinal ligaments and involvement of the hip joints are usually very late manifestations. It is of interest to note that two of the original writers on the subject, Bechterew (1897) and
Strumpell (1897) were neurologists, and they were particularly interested in the neurological manifestations of spondylitis. Bechterew summarized his opinions as follows: (a) that the disease was associated with a major or minor immobility or at least an insufficient mobility of the whole spine or of only certain parts of the spine; $(b)$ that a curvature with the convexity towards the back of the spine mainly in the upper dorsal regions usually develops; (c) that there occurs a paretic condition of the muscles of the trunk, the neck, and extremities, in most cases with slight atrophy of the muscles of the back and the shoulder blades; $(d)$ that there is diminution in sensation mainly in the regions provided by the cutaneous branches of the dorsal and lower cervical nerves, and at times also in that provided by the lumbar nerves; $(e)$ that in a few cases symptoms of irritation of the motor nerves is present in the form of tetanic fibrillations of the hands and feet.

Strumpell was particularly impressed with the peculiar gait of these patients. He wrote as follows: "A peculiar and, as it appears to us, a distinct disease may be mentioned here during which a complete ankylosis of the whole spine and hip joints develops very slowly without pain in such a way that the head, trunk and thighs are firmly attached to each other and completely stiff, while all other joints maintain their normal mobility. It is evident that this can cause very peculiar manifestations of the habitus and the gait."

Boland and others (1946) found the total protein of the spinal fluid raised to between 45 and $105 \mathrm{mg}$. per $100 \mathrm{c.cm}$. in 40 per cent. of the cases studied. The sedimentation rate and leucocyte counts were raised to 75 per cent. of 200 (195 men and 5 women) cases studied by the author. The prostate was found markedly atrophied in 60 per cent. of the male cases, and this sometimes makes it quite difficult to obtain prostatic fluid even by vigorous massage; a study of the aetiology of this prostatic atrophy seems desirable. It is an accepted fact that 
ankylosing spondylitis occurs in the ratio of 10 men to one woman, whereas in rheumatoid arthritis the ratio is 4 women to 1 man.

The following cases are illustrative of the bearing of spondylitis upon pregnancy and parturition.

\section{Case Histories}

Case 1.-A white woman aged 36, was seen on Sept. 2, 1945 , complaining of pain in the lower back. She had noted pain in the right sacro-iliac area on and off since the spring of 1945. Also, she had had almost constant shoulder pains for two years. Pain in the left sacro-iliac area had been noted during the past month, particularly when getting up from the prone position. Low-grade back pain had been present constantly since the spring of 1945. There had been no history of injury. The patient was two months pregnant. She had been married fifteen years and had one child. One infected tooth had been removed two years previously and the appendix at the age of 14. The remaining systems showed no abnormalities. The family history is interesting in that the mother and sister both have rheumatoid arthritis.

Physical examination showed an undernourished white woman whose naked weight was $103 \mathrm{lb}$., height $5 \mathrm{ft} .7 \frac{1}{4}$ in. (standard weight $119 \mathrm{lb}$.), temperature $98^{\circ} 8^{\circ} \mathrm{F}$., pulse 88 , and blood pressure $112 / 70 \mathrm{~mm}$. Hg. The pupils reacted to light and accommodation. The tonsils had been removed. The teeth and posterior pharynx appeared normal. Examination of the neck and lungs was negative. A grade 3 to 4 pulmonary systolic murmur was heard, and the second pulmonary sound was markedly accentuated. Fluoroscopic examination of the heart and lungs was negative. Vaginal examination showed the uterus to be midway between the symphysis and the umbilicus. Rectal examination was negative. There was unusual tenderness upon percussion over the second lumbar vertebra. The Lasegue sign was negative. The deep reflexes were equal and active. The vibratory sense was intact.

Urinalysis was negative. Red blood cells were $4,440,000$ per c.mm. of blood, $\mathrm{Hb} 12.5 \mathrm{~g}$., white blood cells 6,900 per c.mm. The Schilling differential was: Stabzellen 10, segmented cells 40 , lymphocytes 36 , monocytes 9 , eosinophils 3 , basophils 2 . The sedimentation rate was normal at $10 \mathrm{~mm}$. per hour. Throat culture revealed non-haemolytic streptococci. The Wassermann reaction was negative.

$X$-ray examination of the lumbo-sacral area on Sept. 28, 1945, revealed typical changes of ankylosing spondylitis in the right sacro-iliac area. There was some increased density on either side of the sacro-iliac joint, and the joint surface itself appeared hazy. Also, there were slight bony changes on the bodies of the lower dorsal vertebrae. A diagnosis of spondylitis was made (Fig. 1). The patient was advised to rest on a firm bed and to take warm baths. The iron deficiency anaemia was treated with ferrous sulphate.

The pain in the lower back was not relieved until January, 1946. This was at the beginning of the last trimester of pregnancy. From this period on the patient had complete relief from her back symptoms. A repeated $x$-ray examination of the lumbo-sacral area was taken on Jan. 2, 1946 (Fig. 2). No evidence of progress of the arthritis was noted. In fact, the joint space in the right sacro-iliac area appeared more normal. There was evidence of a single pregnancy. The foetal head was noticed in the pelvis, there being no disproportion between the foetal head and the pelvic outlet. In April, 1946, the patient was delivered of a $7 \mathrm{lb}$. baby girl. Labour took twelve hours and was normal. The clinical symptoms have been absent up to the date of writing (June 30, 1948).

This is a case of ankylosing spondylitis observed during pregnancy. There was indication that pregnancy seemed to benefit the spondylitis, which in no way interfered with a normal delivery.

Case 2.-A white women aged 31 was seen on Aug. 22, 1945 , complaining of pain and stiffness of the lower back. Stiffness in the lower back was noticed during the seventh month of pregnancy three years before, and she had had come stiffness in the lower back ever since. The back symptoms had been markedly relieved during her previous pregnancy, approximately eighteen months before. It is reasonable to assume after a study of the lumbo-sacral radiograph that the advanced changes in the sacro-iliac joints were present for three to five years. The symptoms had become more aggravated during the last three weeks, and the patient had noticed pain radiating down the left sciatic nerve during this time. One infected tooth was removed four months before, and the appendix in 1932. The patient had lost $12 \mathrm{lb}$. in the past ten weeks.

She had been married five years and had two children. The first child was born on Aug. 25, 1942. The delivery was normal, the period of labour being ten hours. The second child was born on Feb. 23, 1944. The period of labour was three hours and the delivery normal. In both cases the postpartum period was normal.

The physical examination revealed a slightly overnourished female whose naked weight was $162 \mathrm{lb}$., height $5 \mathrm{ft}$. $10 \frac{1}{2}$ in. (standard weight $157 \mathrm{lb}$.), temperature $99^{\circ} \mathrm{F}$., pulse 82 , and blood pressure $120 / 80 \mathrm{~mm}$. $\mathrm{Hg}$. The pupils reacted to light and accommodation. Some teeth had been filled, and their condition was satisfactory. The tonsils were somewhat hypertrophied. The posterior pharynx appeared normal. Examination of the neck, lungs, heart, and abdomen showed nothing abnormal except for an appendicectomy scar. Vaginal and rectal examinations were negative. There was tenderness upon percussion over both sacro-iliac joints. The Lasegue sign was positive on the left side. The deep reflexes were equal and active. The vibratory sense was intact. Urinalysis was negative. The red cell count was $5,100,000$ per c.cm. of blood, Hb $14.3 \mathrm{~g}$., white cells 5,050 per c.mm. The Schilling differential was: Stabzellen 4, segmented cells 63 , lymphocytes 27 , monocytes 3 , eosinophils 3. The sedimentation rate was normal at $13 \mathrm{~mm}$. per hour. Throat culture revealed non-haemolytic streptococci. The Wassermann reaction was negative.

Lumbo-sacral radiographs taken Aug. 22, 1945, revealed marked changes around the sacro-iliac joints. 


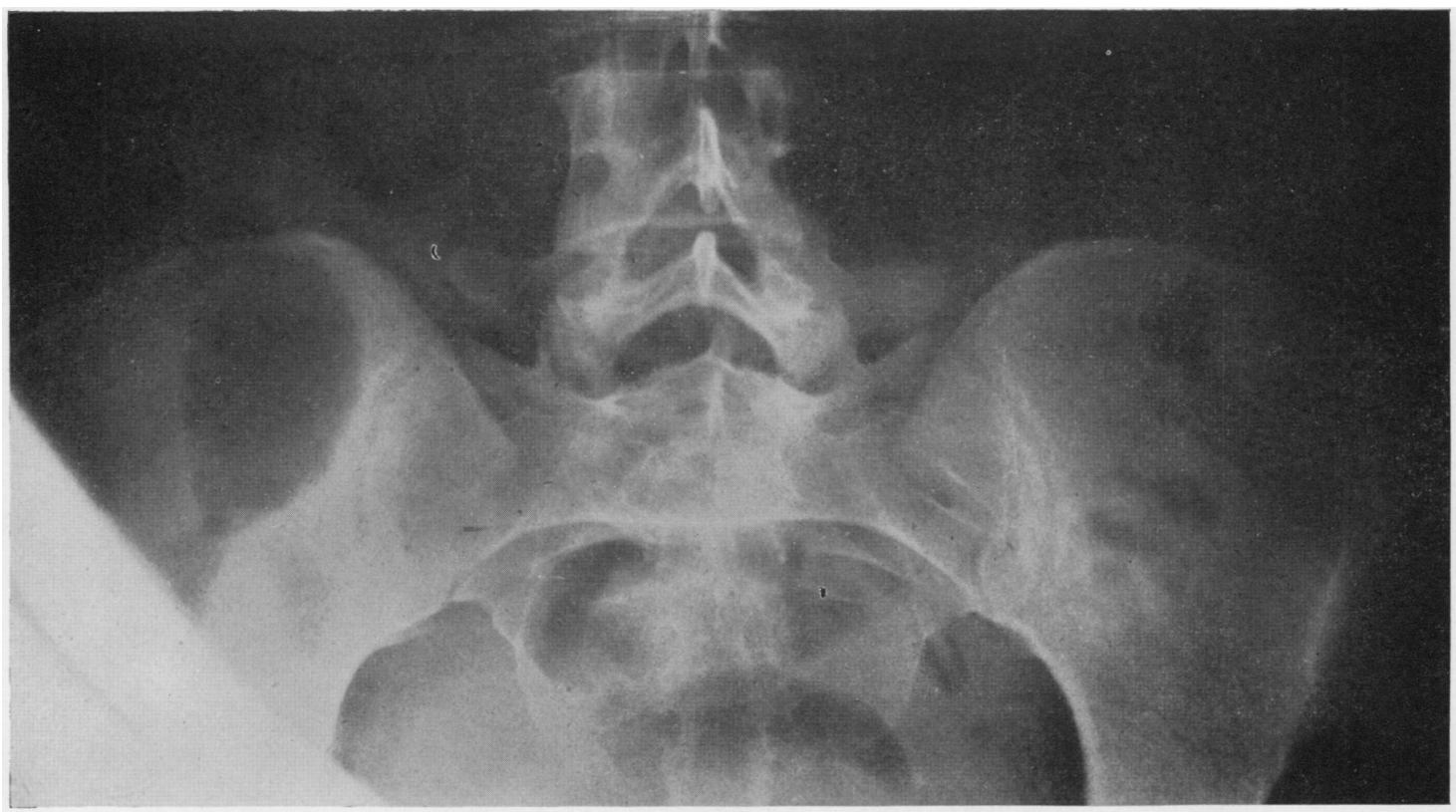

Fig. 1.-Case 1: a lumbo-sacral radiograph taken on Sept. 28, 1945, showed typical changes of ankylosing spondylitis in the right sacro-iliac area. There was some increased density on either side of this joint, and the surface itself appeared hazy.

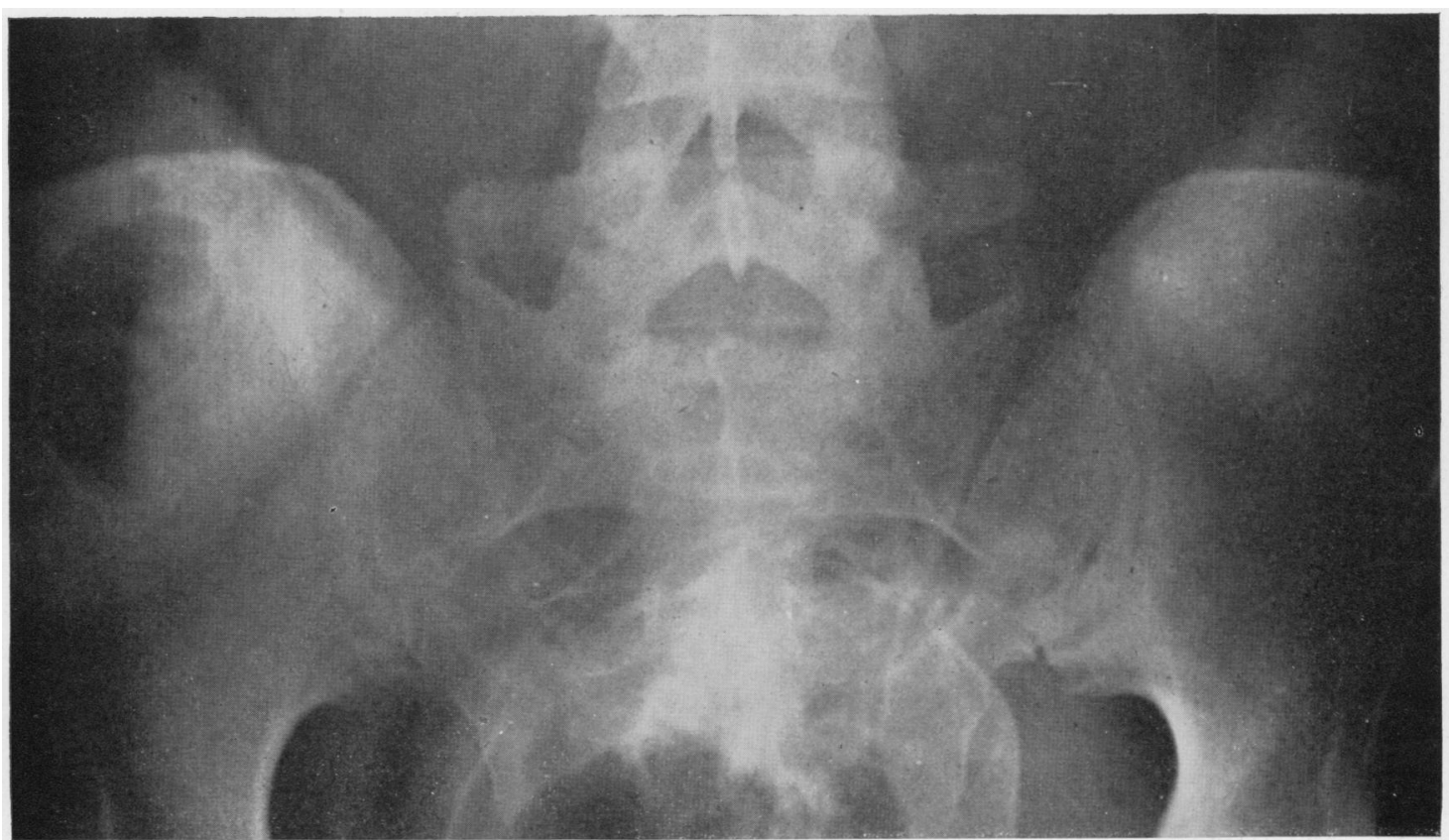

Fig. 2.-Case 1: a lumbo-sacral radiograph taken on Jan. 2, 1946 (six months pregnancy) showed no progression of the arthritis. In fact the joint space in the right sacro-iliac area appeared more normal. 


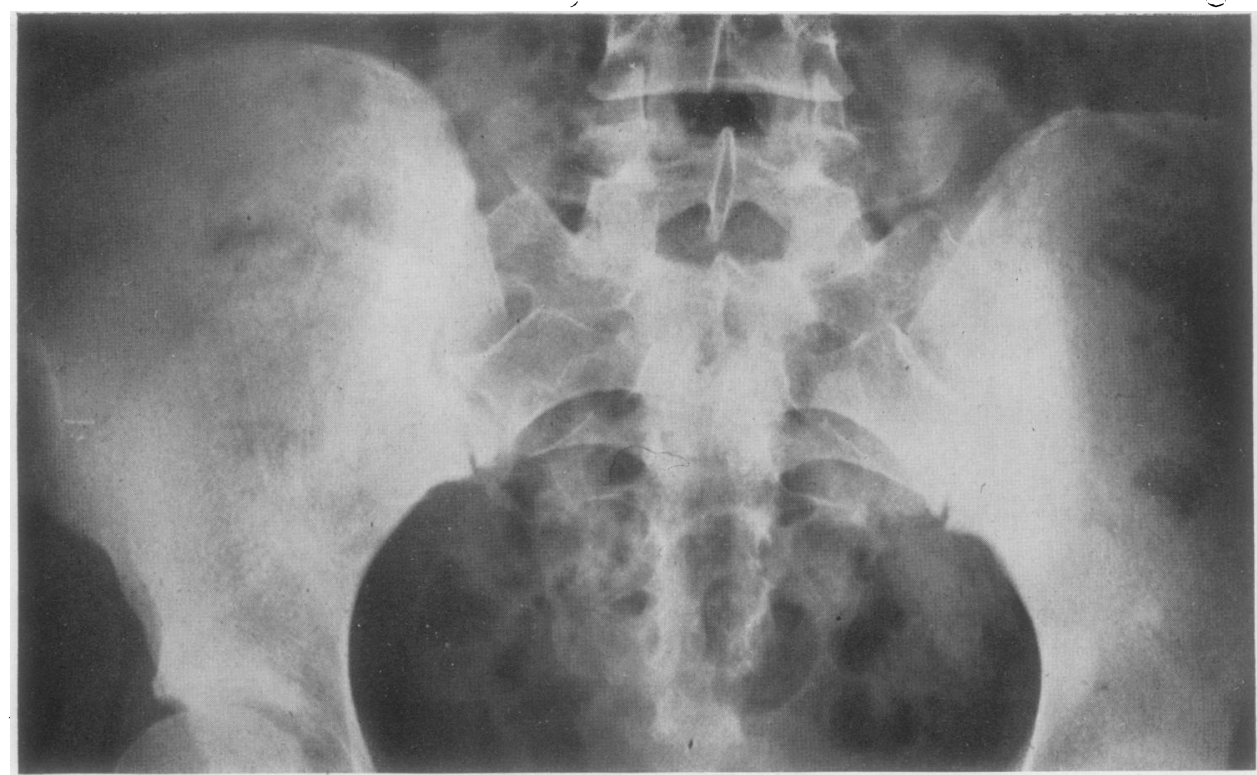

Fig. 3.-Case 2: a lumbo-sacral radiograph taken on Aug. 22, 1945, showed marked changes in both sacro-iliac joints diagnostic of ankylosing spondylitis.

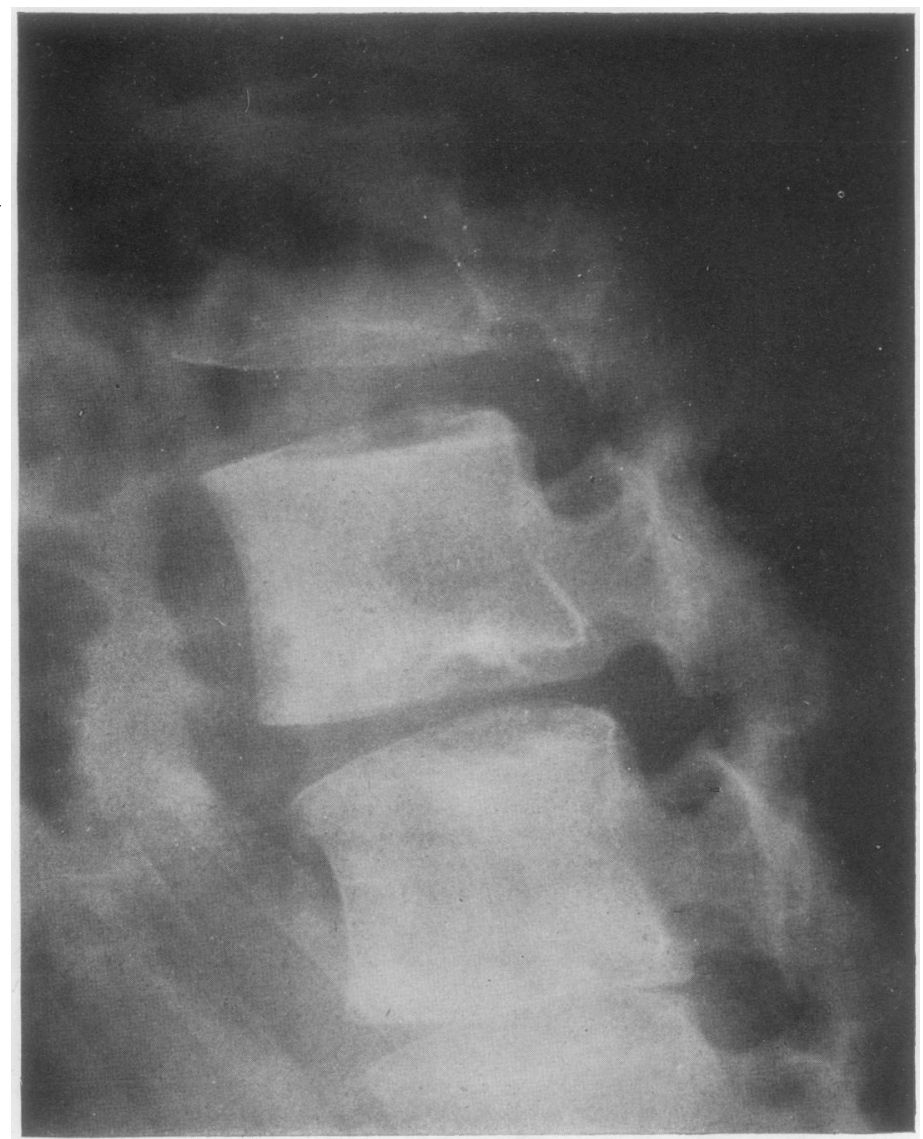

FIG. 4.-Case 2: note straightening of lumbar spine characteristic of ankylosing spondylitis. 

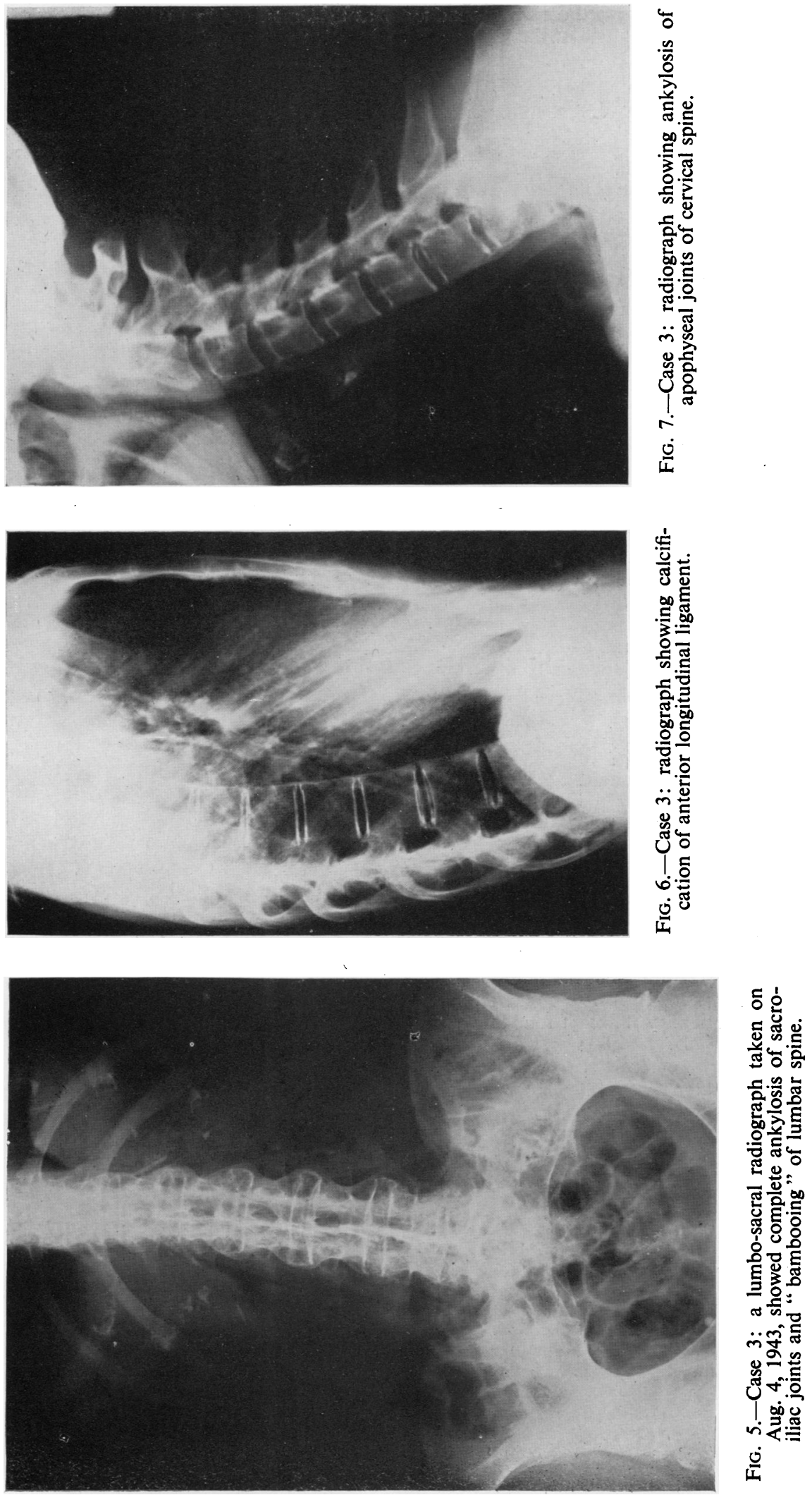
These changes consisted of increased density around the sacro-iliac joints and loss of outline of the joint spaces. The changes were much more conspicuous on the right side in the region of the ilium. No gross changes were noted around the body of the vertebrae. There was slight loss of the lumbar curve observable in the lateral film. The hip joints were normal. A spina bifida was present in the upper sacral segments (Fig. 3 and 4).

A diagnosis of ankylosing spondylitis was made. The patient was ordered rest on a firm bed, with daily warm baths, and was given the carbohydrate fraction of haemolytic streptococci. Clinical improvement began two months after treatment and has been maintained ever since.

This woman with ankylosing spondylitis went through two normal pregnancies. The $x$-ray findings were sufficiently advanced to indicate that the spondylitis was present during both pregnancies.

Case 3.-A white woman aged 55 was seen on Aug. 4, 1943. Her chief complaint was that she had had stiffness of the neck for a year. The joint symptoms had begun thirty years ago at seven months gestation. First she noticed lameness in the left " hip", and later symptoms appeared in the joints of the shoulders and back. More recently there has been pain and stiffness of the hands and knees. There had been no movement of the neck for one year, and pain and stiffness of the back had existed for fifteen years. Girdle-like constriction pain had been present in the chest during the past year. She had lost five pounds in weight during the past eight weeks. The appetite had been poor.

The patient had been married thirty-four years and had one child, now thirty years old. The patient says she was " not long in labour"; however, low forceps were required for delivery. She reiterates that her first symptoms were pains of the right sacro-iliac area during pregnancy. Her family physician made a diagnosis of sacro-iliac arthritis. The tonsils were removed some years ago.

The physical examination revealed a thin white woman whose naked weight was $92 \mathrm{lb}$., height $5 \mathrm{ft} .3 \mathrm{in}$. (standard weight $141 \mathrm{lb}$.), temperature $98 \cdot 6^{\circ} \mathrm{F}$., pulse 100 , and blood pressure $160 / 80 \mathrm{~mm}$. $\mathrm{Hg}$. The pupils reacted to light and accommodation. All except four lower teeth had been removed. The tonsils were out, and the posterior pharynx appeared normal-also the neck, lungs, and heart. Abdominal, rectal and vaginal examinations were negative. All degrees of extensive deformity characteristic of advanced rheumatoid arthritis were present in the proximal interphalangeal joints. The spine was a typical pokerback spine, with no movement except at the hip joints and no movement in the neck. Tenderness was present upon percussion over both sacro-iliac areas. The deep reflexes were equal and active, and the vibratory sense was intact.

Urinalysis was negative. The red cell count was 4,030,000 per c.mm. of blood, $\mathrm{Hb} 11 \mathrm{~g}$., white cell count 9,800 per c.mm. The Schilling differential was: Stabzellen 12, segmental cells 57 , lymphocytes 26, monocytes 5 . The sedimentation rate was slightly raised at $0.44 \mathrm{~mm}$. (normal 0.08 to 0.35 ). The Wassermann reaction was negative.

$X$-ray examination of the cervical, dorsal, and lumbosacral areas revealed the marked calcification of the longitudinal ligaments of the dorsal and lumbar regions. This calcification extended upward as high as the lower border of the seventh cervical vertebra. Calcification was more extensive in the ligaments around the lumbar area. In the sacro-iliac joints there were advanced changes typical of ankylosing spondylitis. The joints were indistinctly outlined.

This patient had advanced ankylosing spondylitis, and had symptoms during her pregnancy. It is difficult for anyone to be specific about symptoms or time after thirty years, but I believe it is justifiable to assume that she did have early ankylosing spondylitis during her pregnancy. It is of interest to note that this patient is the only one of the three who states that her symptoms developed in the latter part of pregnancy, though, owing to the long period of time that has elapsed, her statement may or may not be true. Low back pain is not an uncommon symptom in pregnancy. However, the $x$-ray findings shown in Fig. 3, 5, 6, and 7 are of spondylitis of many years' duration. Also, the early diagnosis of sacro-iliac arthritis by her family physician when the patient was seven months pregnant cannot be ignored.

\section{Conclusions}

Ankylosing spondylitis, although it affects the 8 skeletal structure, is no hindrance to pregnancy. Instrumentation (low forceps) was used to effecto delivery of one child out of four deliveries. The other three deliveries were spontaneous and normal. Several reasons may exist for this situation. Ankylosing spondylitis is a self-arresting and mild disease as a rule, in women. The disease may show retrogression during pregnancy, as evidenced by $x$-ray films of Case 1. Women in the child-bearing age are still young and have not had the disease long enough for it to complete its ravaging effects on the skeletal system.

\section{REFERENCES}

Bechterew, W. von (1897). Dtsch. Z. Nervenheilk., 11, 327.

Boland, E. W., Headley, N. D., and Hench, P. S. (1946). J. clin. Invest., 25, 918 .

Buckley, C. W. (1936). Acta Rheum. Amst., 8, 24.

Freyberg, R. Personal communication.

Graham, W., and Ogryzlo, M. A. (1947). Canad. med. Ass. J., 57, 16.

Grant, J. C. B. (1940). " A Method of Anatomy." Williams and Wilkins Co. Baltimore. Second Edition, p. 310.

Hench, P. S., Slocumb, C. H., and Polley, H. F. (1947). Med. Clin. N. Amer., 31, 879.

Polley, H. F., and Slocumb, C. H. (1947). Ann. intern. Med., 26, 240.

Strumpell, A. (1897). Dtsch. Z. Nervenheilk., 11, 338. 


\section{Spondylite Ankylosante et Grossesse}

\section{RÉsumé}

On ne trouve pas mention dans la littérature sur la spondylite ankylosante de cas dans lesquels cette maladie ait gêné la grossesse ou le travail normal de parturition, bien qu'elle soit susceptible, à mesure qu'elle progresse, d'exercer une action défavorable sur ces fonctions.

L'auteur rapporte trois observations illustrant les effets de la spondylite ankylosante dans la grossesse et la parturition.

L'auteur conclut que la spondylite ankylosante, bien qu'elle affecte la structure du squelette, ne gêne pas la grossesse. Sur quatre accouchements on n'a da recourir à l'emploi d'instruments (forceps bas) que dans un seul cas. Les trois autres accouchements ont été spontanés et normaux. Il peut y avoir plusieurs explications de cette situation. La spondylite ankylosante chez les femmes est généralement une maladie bénigne qui tend vers une amélioration spontanće. La maladie peut même régresser au cours de la grossesse comme le montrent les radiographies du sujet 1 . Les femmes susceptible de devenir enceintes sont encore jeunes et n'ont pas été atteintes par la maladie assez longtemps pour qu'elle ait pu exercer ses ravages sur le squelette. 